\title{
DEVELOPMENT OF MOLDED JELLY MARMELAD TECHNOLOGY WITH THE INTRODUCTION OF FOOD ADDITIVE “MAGNETOFOOD”
}

\section{TSYKHANOVSKA*}

\author{
Department of Food and Chemical Technologies, Ukrainian Engineering and Pedagogical Academy, Kharkov, UKRAINE \\ "e-mail: cikhanovskaja@gmail.com
}

\begin{abstract}
Lack of domestic raw materials, a significant portion of imported high-cost ingredients and increasing competitiveness make manufacturers look for new technological solutions in order to improve the consumer properties of marmalade products. A promising trend in the field of jelly and marmalade products is the creation of products with high quality and long shelf life. For this purpose various food additives, i.e. improvers, are used in jelly marmalade technology. As an improver of shaped jelly marmalade, we have developed and proposed "Magnetofood" food additive, which is nanopowder with a particle size of (70-80) nm. "Magnetofood" is a food additive with high functional and technological potential. "Magnetofood" additive can independently generate structural and mechanical properties of jelly masses, and also it can influence the gelling agent by entering into chemical and electrostatic interactions with it. Therefore the "Magnetofood" food additive can simultaneously affect several technological properties in the food jelly system: to be a stabilizer, a thickener and a gelling agent. Due to Fe (II), nanosize, developed active surface, bacteriostatic character, high thermal stability, "Magnetofood" has reducing, antioxidant, antimicrobial, sorbing, complexable, emulsifying, moisture-retaining, fat-retaining, water-binding, stabilizing, and structuring properties. It makes possible to recommend "Magnetofood" as an additive of complex action to improve the quality and extend the shelf life of shaped jelly marmalade. The influence of "Magnetofood" food additive on organoleptic, physical and chemical, microbiological parameters of test samples of agar-and pectin-based shaped jelly marmalade has been studied.
\end{abstract}

Keywords: technology; "Magnetofood" food additive; shaped jelly marmalade; quality indicators.

\section{РОЗРОБКА ТЕХНОЛОГІЇ ФОРМОВОГО ЖЕЛЕЙНОГО МАРМЕЛАДУ З ВНЕСЕННЯМ ХАРЧОВОЇ ДОБАВКИ “МАГНЕТОФУД"}

\section{I. В. ЦИХАНОВСЬКА*}

кафедра Харчових та хімічних технологій, Украӥнська інженерно-педагогічна академія, м. Харків, УКРАЇНА

\begin{abstract}
АНОТАЦІЯ Дефіцит вітчизняної сировини, значна частка імпортних інгредієнтів з високою вартістю, зростаюча конкурентоспроможність змушують виробників иукати нові технологічні рішення для підвищення споживчих властивостей мармеладної продукції. Перспективним напрямком в галузі желейно-мармеладних виробів є створення продукиії, яка має високі показники якості і тривалий термін зберігання. 3 иією метою у технології желейного мармеладу використовуються різні харчові добавки - поліпшувачі.В якості поліпшувача формового желейного мармеладу нами розроблено та запропоновано харчову добавку “Магнетофуд” - нанопорошок з розміром частинок (70-80) нм. "Магнетофуд"- харчова добавка з високим функиіонально-технологічним потенціалом. Добавка "Магнетофуд” може як самостійно формувати структурно-механічні властивості желейних мас, так і впливати на гелеутворювач, вступаючи 3 ним в хімічні і електростатичні взаємодії. Тому, харчова добавка "Магнетофуд" можє впливати одразу на декілька технологічних властивостей у харчовій желейній системі: бути стабілізатором, загусником, драглеутворювачем. $3 а$ рахунок $\mathrm{Fe}$ (II), нанорозмірів, розвиненої активної поверхні, бактеріостатичності, високої термостабільності "Магнетофуд" має відновні, антиоксидантні, антимікробні, сорбиійні, комплексоутворюючі, емульгуючі, вологоутримуючі, жироутримуючі, вологозв'язуючі, стабілізуючі, структуруючі властивості. Це дозволяє рекомендувати "Магнетофуд" як добавку комплексної дї для підвищення якості та подовження терміну зберігання формового желейного мармеладу.Досліджено вплив харчової добавки “Магнетофуд” на органолептичні, фізико-хімічні, мікробіологічні показники дослідних зразків формового желейного мармеладу на агарі і пектині.
\end{abstract}

Ключові слова: технологія; харчова добавка “Магнетофуд”; формової желейний мармелад; показники якості.

\section{Introduction}

The range of marmalade on the market today is represented mainly by a group of jelly marmalade, which has an attractive appearance, a variety of shapes, a pleasant smell and taste, is quite simple to manufacture. That is why it is popular among the population and manufacturers. The effectiveness of technologies for the production of molded jelly marmalade in a market economy is determined by the introduction of competitive resource-saving technologies, the achievement of high technical and economic indicators of production, the possibility of processing raw materials with different properties while ensuring the stable quality of marmalade products and extending their shelf life. The range of jelly marmalade produced today, its composition and technologycal production process is a reflection of innovative technologies aimed at improving the technical and technological level of production, improving the 
quality and increasing the range of marmalade products [1-3].

Among the priority areas for expanding the range by improving the technology of molded jelly marmalade are the following: the use of new raw materials, that provide an opportunity to change or adjust the functional and technological properties of jelly masses, as well as texture, quality indicators and increase the shelf life of marmalade products [4-11].

Market trends in forming a range of molded jelly marmalade are due to innovations in its recipe composition, aimed at reducing its cost, improving its quality and shelf life.

It is especially important to note that the prices for raw materials rise every year. Unfortunately, pectin and agar, the two main gelling agents, traditionally used in molded jelly marmalade technology, are expensive imported raw materials. So, from the beginning of 2014 and at the end of 2016, the prices for agar and the food pectin increased on average by $(3,5-4,0)$ times; the search for new raw materials of domestic production that reduces the cost price while maintaining the quality is an urgent task for the production of molded jelly marmalade [5-8].

Thus, one of the possibilities for creating competitively priced products is the economical and efficient use of expensive raw materials, including gelling. There are various ways to solve this issue, but the main one is the introduction of competitive resourcesaving technologies.

Many specialists, in particular, scientists of NUHT, KDUKhT, ONAKhT (A. M. Dorokhovich, V. F. Pertsev, V. I. Obolkina, G. A. Magomedova, V. V. Rumyantseva, Yu. V. Kambulova, Tung-Shan Chen, Yoslyn MA, A. Lee, D. Storey and others) are actively developing modern technologies of jelly marmalade using new types or modifications by gelling agents, thickeners, mixtures of unconventional substances capable of jelly formation (agar and gelatin, agar and alginate, agar and xampana, agaroid, furcelaran and sodium carboxymethylcellulose, pectin and alginate, locust bean gum, tara gum, etc.), allowing to reduce the costs of the main gelling agents, and thereby reduce the cost of production. For the extraction of artificial dyes and flavors from the recipe composition, the introduction of krias-powders, cryo-pastes, extracts of medicinal plants, etc. is proposed. [8-16]. However, with regard to research on the effects of nanopowder additives, in particular, the food additive "Magnetofood" [Patent UA No. 126502, MPK A 23L 13/40, A23L 33/10. Food supplement "Magnetofood"] on the processes of structure formation of jelly masses during jelly marmalade production and on the indicators of the quality of the finished product, there is no any data and more research is needed.

"Magnetofood" is a food additive, it has a certain functional and technological potential and can independently form the structural and mechanical properties of jelly masses and also affect the gelling agents, entering into chemical and electrostatic interactions with it. Therefore, the food additive
"Magnetofood" can perform several technological functions in the system at once: act as a stabilizer, at the same time increasing the viscosity of the system or forming a gel. That is, it can perform the functions of both a thickener and gelling agents. Although the food additive "Magnetofood" is not a surfactant, it can stabilize disperse systems (emulsions, suspensions) due to its thickening and thixotropic properties, preventing their division. Changing the fluid properties of a liquid disperse system in the presence of the food additive "Magnetofood" leads not only to the stabilization of the system, but also to the formation of a certain consistency. Functional and technological properties of the additive "Magnetofood" in food systems include: water-binding and water-holding ability; stabilization of emulsions and suspensions; regulation of fluid properties; formation of stable gels at room temperature. The thixotropic properties of gels with the use of the food additive "Magnetofood" are manifested in reversible changes in the structure of the gel during its deformation and subsequent removal of the mechanical load [17-22].

Thus, the use of the food additive "Magnetofood" as a thickener and stabilizer of jelly-marmalade products will allow to solve the following tasks: to improve the consumer properties of the finished product: compaction of the consistency, cutting improvement (glossy cut) and provision of elasticity; reduce syneresis during storage of products.

In this regard, the study of the functional and technological potential of natural mineral resources, in particular, nanopowder food additives, from the point of view of the impact on the quality, shelf life and economic efficiency of the production of jelly confectionery masses and marmalade products made from them is relevant.

To solve this urgent problem, an integrated approach to the development of technological solutions for the production of jelly marmalade products is needed, which should be based, on the one hand, on the study of the influence of nanopowder mineral additives on the structural and mechanical properties of jelly masses to substantiate their functional and technological potential, that is important to ensure the quality characteristics of molded jelly marmalade in terms of physical and chemical, organoleptic and safety indicators, on the other hand, on the technological process of jelly marmalade products, that affects the economic efficiency of the production.

Within the work considered, it was of interest to substantiate the expediency of improving the technology of molded jelly marmalade using the food additive "Magnetofood".

\section{Literature data analysis and problem formulation}

The confectionery industry is one of the active users of food additives, improvers in the manufacture of products. The use of food additives in the industry of sweets, in particular jelly marmalade, is caused by a number of circumstances; reasons and directions of use of 
food additives by the confectionery industry. Recently, there have been numerous studies on search for new lowcost gel-forming components, improving structural and mechanical, physical and chemical, and organoleptic indicators of jelly masses and finished products, as well as partial or full replacement of traditional gelling agents, in particular, agar and pectin - imported products with high cost price [8-12,22-46].

In order to improve the structural and mechanical properties of jelly masses, it is proposed to use pectic substances obtained from non-traditional raw materials, such as food industry waste (canning, wine-making, sugar-beet industries) and agriculture (seed-growing state farms, cotton growing, melon-growing) [9,23,24]; as well as alternative raw materials: chitosan, herbal, vegetable and fruit-vegetable products [14,25-27].

Some scientists have developed combined systems with gelling agents to control the rheological and structural and mechanical properties of jelly semi-finished products and products, in particular the combination of gelatin with pectin, with sulfated polysaccharides, gelatin - k-carrageenan, gelatin - LM pectin [28-30]; pectin with hydrocolloids (Herbagel SW-010, ricogel 8100), LM pectin - k-carrageenan [30-32]; agar with the concentrate of animal proteins "Scanpro" [30].

To improve the plastic strength of the jelly and the texture of jelly products in the production of marmalade, various hydrogels are widely used, showing the properties of thickeners, a gelling agent and stabilizers carrageenan and its sodium, potassium, ammonium salts, including furcelllaran; xanthan, tara gum, guar gum, locust bean gum, xanthan gum and others [32-35].

Numerous studies have been carried out to study the influence of modifying additives on the structural and mechanical properties of jellies: sodium carboxymethylcellulose (Na-CMC) and ferric chloride to increase the gel-forming ability of sulfate polysaccharides $[29,26]$; sodium lactate, sodium citrate and glycerin in the amount of $(0,1-0,2) \%$ of the total mass to increase the gel-forming ability of red seaweed polysaccharides and, as a result, to reduce their content by (35-40)\% $[36,37]$; mannitol or sodium alginate in the amount of $(0,08-0,09) \%$ to increase the strength of the jelly to $(40-$ $60) \%$ and reduce the ammount of agar (agaroid, furcelarran) [38-40].

Analysis of information sources [4-12,22-46] shows the lack of data on jelly marmalade technologies using nanopowder additives that have thickening, gelforming, stabilizing abilities; improve structural and mechanical properties of jelly masses and quality indicators and shelf life of finished products. As an additive improver for food systems, we have developed and proposed the food additive "Magnetofood" [TU U 10.8-2023017824-001: 2018]. It is an ultra-fine powder with a large specific and highly active surface.

In food systems, "Magnetofood" exhibits reconstructive, antioxidant, sorption, bacteriostatic, complexing, emulsifying, water-holding, fat-holding, water-binding, stabilizing, structuring properties [17-22].
In this regard, it is relevant to improve the recipe composition and the existing technology of molded jelly marmalade with the introduction to the recipe composition the food additive "Magnetofood".

\section{Purpose and objectives of research}

The aim of the work is to improve the technology of molded jelly marmalade using the food additive "Magnetofood".

To achieve the main goal, the following tasks were set:

to study the influence of the food additive "Magnetofood" on the physical and chemical properties (mass fraction of moisture, total acidity) of test samples of the molded jelly marmalade on agar and pectin;

to study the influence of the food additive "Magnetofood" on the organoleptic indicators (taste, smell, color, consistency, form) of test samples of molded jelly marmalade on agar and pectin;

to study the effect of the food additive "Magnetofood" on the sorption properties of test samples of molded jelly marmalade on agar and pectin during a regulated shelf life;

to study the effect of the food additive "Magnetofood" on the microbiological indicators of test samples of molded jelly marmalade on agar and pectin during a regulated shelf life;

to establish a rational mass fraction of the food additive "Magnetofood" in the compositions of molded jelly marmalade on agar and pectin;

to develop a technological scheme for the production of molded jelly marmalade using the food additive "Magnetofood".

\section{Statement of basic materials}

The object of the research is the technology of molded jelly marmalade on agar and pectin. The subject of the research is the model samples of jelly marmalade on agar and pectin, which are based on the basic compositions № 11 and № 49 [47] and are shown respectively in Tables 1 and 2 .

Preparation of test samples of marmalade was carried out according to the traditional technology of molded jelly marmalade according to the classical composition [15, 47], Table 1 and 2.

Organoleptic evaluation of the quality of jelly marmalade test samples was carried out according to DSTU 4683:2006 on a 5-point scale using weighting factors that take into account the significance of each indicator: shape, consistency, color were determined by inspection of controlled marmalade products.

In assessing the smell of marmalade, attention was paid to the presence or absence of foreign, unusual odors. The acidity of the finished products was determined by the titrimetric method using phenolphthalein according to DSTU 5024: 2008. 
Table 1 - The compositions of jelly marmalade on agar (control) and with different mass fraction of the food additive "Magnetofood"

\begin{tabular}{|l|c|c|c|c|}
\hline \multirow{2}{*}{ Raw material } & \multicolumn{4}{|c|}{$\begin{array}{l}\text { Raw material consumption per 1 ton of } \\
\text { finished products, kg }\end{array}$} \\
\cline { 2 - 5 } & $\begin{array}{c}\text { Sample 1 - } \\
\text { control }\end{array}$ & Sample 2 & Sample 3 & Sample 4 \\
\hline $\begin{array}{l}\text { Sanding sugar } \\
\text { for sprinkling }\end{array}$ & 86,6 & 86,6 & 86,6 & 86,6 \\
\hline $\begin{array}{l}\text { Sanding sugar } \\
\text { in jelly }\end{array}$ & 525,6 & 525,6 & 525,6 & 525,6 \\
\hline Molasses & 262,7 & 262,7 & 262,7 & 262,7 \\
\hline Agar & 10,5 & 10,5 & 10,5 & 10,5 \\
\hline Citric acid & 11,8 & 11,8 & 11,8 & 11,8 \\
\hline $\begin{array}{l}\text { Various } \\
\text { essences }\end{array}$ & 1,6 & 1,6 & 1,6 & 1,6 \\
\hline Various dyes & 0,5 & 0,5 & 0,5 & 0,5 \\
\hline $\begin{array}{l}\text { Food additive } \\
\text { "Magnetofood" }\end{array}$ & - & 1,0 & 1,5 & 2,0 \\
\hline
\end{tabular}

Table 2 - The compositions of jelly marmalade on pectin and with different mass fraction of food additive "Magnetofood"

\begin{tabular}{|l|c|c|c|c|}
\hline \multirow{2}{*}{ Raw material } & \multicolumn{4}{|c|}{$\begin{array}{l}\text { Raw material consumption per 1 ton of } \\
\text { finished products, kg }\end{array}$} \\
\cline { 2 - 5 } & $\begin{array}{c}\text { Sample 5 - } \\
\text { control }\end{array}$ & Sample 6 & Sample 7 & Sample 8 \\
\hline $\begin{array}{l}\text { Sanding sugar } \\
\text { for sprinkling }\end{array}$ & 86,6 & 86,6 & 86,6 & 86,6 \\
\hline $\begin{array}{l}\text { Sanding sugar } \\
\text { in jelly }\end{array}$ & 718,9 & 718,9 & 718,9 & 718,9 \\
\hline Molasses & 262,7 & 262,7 & 262,7 & 262,7 \\
\hline Pectin & 18,0 & 18,0 & 18,0 & 18,0 \\
\hline Citric acid & 12,0 & 12,0 & 12,0 & 12,0 \\
\hline Sodium lactate & 10,0 & 10,0 & 10,0 & 10,0 \\
\hline $\begin{array}{l}\text { Various } \\
\text { essences }\end{array}$ & 1,6 & 1,6 & 1,6 & 1,6 \\
\hline Various dyes & 0,6 & 0,6 & 0,6 & 0,6 \\
\hline $\begin{array}{l}\text { Food additive } \\
\text { "Magnetofood" }\end{array}$ & - & 1,0 & 1,5 & 2,0 \\
\hline
\end{tabular}

To simulate the storage of marmalade the polyethylene film (PND, 15 microns) was used as a packaging material in the work. Test samples of jelly marmalade 18 hours after casting and cooling were wrapped in film and stored in the dark at a temperature of $(18 \pm 3){ }^{\circ} \mathrm{C}$ and a relative air humidity of $\leq 75 \%$ for 90 days.

At the same time, the sorption properties of the test samples were determined by the strain gauge method $[48,49]$ immediately after sample preparation and during 110 days with an interval of 10 days. When selecting the optimal storage mode, the constancy of the moisture content of jelly marmalade (the moisture content of molded jelly marmalade after production is $0,179-0,181$ $\mathrm{kg} / \mathrm{kg}$ ), which depends on the humidity of the environment and the shelf life of jelly marmalade (days), was chosen as a criterion. The proposed criterion is as follows (1):

$$
Q_{\varphi}=\sum_{i=1}^{N}\left|W_{i}-W_{3}\right| \underset{\varphi=\text { const }}{\longrightarrow} \min
$$

where $\mathrm{N}$ is the amount of tests during storage, pcs; $\mathrm{W}_{3}$ is the normative moisture content equal to $0,18 \mathrm{\kappa г} / \mathrm{\kappa}$; $\mathrm{Wi}$ is the current value of moisture content, $\mathrm{kg} / \mathrm{kg} ; \varphi$ is the humidity of the environment, $\%$.

The list of microbiological indicators, which were used to control the quality of the finished marmalade products, was established in accordance with the requirements of the DSP 4.4.5.078; MBT № 5061-89 and DSTU 4683: 2006.

\section{Research results}

Table 3 shows the results of organoleptic analysis of jelly marmalade test samples with various gelling agents.

From the data of Table 3, it was found that marmalade with the content of the food additive "Magnetofood" $0.15 \%$ by weight of the raw material is the best according to the organoleptic quality indicators compared with other samples. The average score for organoleptic indicators is increased by $(1,3-1,4)$ points compared with the control.

The main physical and chemical characteristics of molded jelly marmalade is acidity and humidity. Data on the effect of the food additive "Magnetofood" on acidity and moisture loss during molding and cooling of marmalade products are presented in Table 4.

The data in Table 4 show that the introduction of the food additive "Magnetofood" in the amount of $(0,10$ $0,20) \%$ by weight of the raw material contributes to the improvement of the physical and chemical indicators of the marmalade test samples: the humidity increases by $(4,8-6,2) \%$ in the samples on agar and $(5,2-6,2) \%$ in the samples on pectin - due to the water-binding and waterholding ability of nanoparticles of the additive "Magnetofood". That is, the presence of the additive "Magnetofood" in the composition contributes to less moisture loss when cooling products after casting marmalade mass into a mold; total acidity decreases by $(5,9-7,4)^{\circ}$ in samples on agar and $(6,1-7,6)^{\circ}$ in samples on pectin - due to the amphoteric character of the additive "Magnetofood" and its ability to interact with acidic substances of jelly-marmalade masses. As a consequence, the gel-forming component (agar, pectin, etc.) is less subject to acid hydrolysis. At the same time, a decrease in acidity (Table 4 ) has practically no effect on the process of gel-formation. It also becomes possible to produce low acidity jelly marmalade, which can be recommended in therapeutic and preventive nutrition. 
Table 3 - Influence of food additive "Magnetofood" on the organoleptic characteristics of jelly marmalade test samples on agar and pectin

\begin{tabular}{|c|c|c|c|c|c|}
\hline $\begin{array}{l}\text { Marma- } \\
\text { lade test } \\
\text { samples }\end{array}$ & Consistency & Aroma & Color & Taste & $\begin{array}{l}\text { Form and } \\
\text { surface }\end{array}$ \\
\hline $\begin{array}{c}\text { Sample 1 } \\
- \\
\text { (control) }\end{array}$ & $\begin{array}{c}\text { Jelly-like } \\
\text { with brittle } \\
\text { structure, } \\
\text { vitreous } \\
\text { fracture }\end{array}$ & $\begin{array}{l}\text { unexp- } \\
\text { ressed }\end{array}$ & $\begin{array}{l}\text { transpa- } \\
\text { rent with } \\
\text { slight } \\
\text { spotting }\end{array}$ & $\begin{array}{l}\text { slightly } \\
\text { empty }\end{array}$ & $\begin{array}{l}\text { distorted } \\
\text { fuzzy } \\
\text { contour }\end{array}$ \\
\hline$\underset{2}{\text { Sample }}$ & $\begin{array}{c}\text { slightly } \\
\text { puffy, jelly- } \\
\text { like with a } \\
\text { homoge- } \\
\text { neous } \\
\text { structure, } \\
\text { transparent } \\
\text { vitreous } \\
\text { fracture }\end{array}$ & \multirow{3}{*}{$\begin{array}{l}\text { pleasant, } \\
\text { characte- } \\
\text { ristic of } \\
\text { marmala- } \\
\text { de }\end{array}$} & \multirow{3}{*}{$\begin{array}{l}\text { transpa- } \\
\text { rent, } \\
\text { smooth, } \\
\text { with a } \\
\text { brown- } \\
\text { cognac } \\
\text { shade, } \\
\text { without } \\
\text { spotting }\end{array}$} & \multirow{3}{*}{$\begin{array}{l}\text { pleasant, } \\
\text { characte- } \\
\text { ristic of } \\
\text { marmala- } \\
\text { de }\end{array}$} & $\begin{array}{c}\text { correct, } \\
\text { with a } \\
\text { fuzzy } \\
\text { contour, } \\
\text { not elastic } \\
\text { enough dry } \\
\text { surface }\end{array}$ \\
\hline Sample & $\begin{array}{c}\text { vitreous, } \\
\text { elastic with } \\
\text { a homoge- } \\
\text { neous } \\
\text { structure, } \\
\text { transparent } \\
\text { vitreous } \\
\text { fracture }\end{array}$ & & & & \multirow{2}{*}{$\begin{array}{l}\text { correct, } \\
\text { without } \\
\text { deforma- } \\
\text { tion, with a } \\
\text { clear } \\
\text { contour, } \\
\text { smooth } \\
\text { elastic dry } \\
\text { surface }\end{array}$} \\
\hline Sample & $\begin{array}{c}\text { vitreous, } \\
\text { slightly } \\
\text { elastic with } \\
\text { a homoge- } \\
\text { neous } \\
\text { structure, } \\
\text { transparent } \\
\text { vitreous } \\
\text { fracture } \\
\end{array}$ & & & & \\
\hline $\begin{array}{c}\text { Sample 5 } \\
- \\
\text { (control) }\end{array}$ & $\begin{array}{l}\text { soft, jelly- } \\
\text { like with } \\
\text { homoge- } \\
\text { neous } \\
\text { structure, } \\
\text { uneven } \\
\text { cleavage at } \\
\text { fracture } \\
\end{array}$ & $\begin{array}{l}\text { unexp- } \\
\text { ressed }\end{array}$ & $\begin{array}{l}\text { transpa- } \\
\text { rent } \\
\text { smooth, } \\
\text { light with } \\
\text { slight } \\
\text { spotting }\end{array}$ & sourish & $\begin{array}{l}\text { with } \\
\text { overlaps, } \\
\text { fuzzy } \\
\text { contour, } \\
\text { matte } \\
\text { elastic dry } \\
\text { surface }\end{array}$ \\
\hline Sample & $\begin{array}{c}\text { jelly-like, } \\
\text { with smooth } \\
\text { transparent } \\
\text { cleavage at } \\
\text { fracture }\end{array}$ & \multirow{3}{*}{$\begin{array}{l}\text { pleasant, } \\
\text { characte- } \\
\text { ristic of } \\
\text { marmala- } \\
\text { de }\end{array}$} & \multirow{3}{*}{$\begin{array}{l}\text { transpa- } \\
\text { rent, } \\
\text { smooth, } \\
\text { with a } \\
\text { brown- } \\
\text { cognac } \\
\text { shade, } \\
\text { without } \\
\text { spotting }\end{array}$} & \multirow{3}{*}{$\begin{array}{l}\text { pleasant, } \\
\text { characte- } \\
\text { ristic of } \\
\text { marmala- } \\
\text { de }\end{array}$} & $\begin{array}{l}\text { correct, } \\
\text { with burrs, } \\
\text { fuzzy } \\
\text { contour, } \\
\text { glossy } \\
\text { elastic dry } \\
\text { surface }\end{array}$ \\
\hline $\begin{array}{c}\text { Sample } \\
7\end{array}$ & \begin{tabular}{|c|} 
slightly \\
puffy, with a \\
smooth \\
transparent \\
cleavage at \\
fracture
\end{tabular} & & & & \multirow{2}{*}{$\begin{array}{c}\text { correct, } \\
\text { without } \\
\text { deforma- } \\
\text { tion, with a } \\
\text { clear } \\
\text { contour, } \\
\text { glossy } \\
\text { elastic dry } \\
\text { surface }\end{array}$} \\
\hline $\begin{array}{c}\text { Sample } \\
8\end{array}$ & \begin{tabular}{|c|} 
dense puffy, \\
with a \\
smooth \\
opaque \\
cleavage at \\
fracture
\end{tabular} & & & & \\
\hline
\end{tabular}

Table 4 - Influence of food additive "Magnetofood" on acidity and moisture loss during molding and cooling of test samples of jelly marmalade on agar and pectin

\begin{tabular}{|c|c|c|c|c|}
\hline \multirow{2}{*}{$\begin{array}{c}\text { Test } \\
\text { samples of } \\
\text { marmalade }\end{array}$} & \multicolumn{3}{|c|}{$\begin{array}{c}\text { Mass fraction of } \\
\text { moisture, } \%,\end{array}$} & \multicolumn{2}{c|}{ Total acidity, $^{\circ}$} \\
\cline { 2 - 5 } & on agar & on pectin & on agar & on pectin \\
\hline $\begin{array}{c}\text { Sample 1- } \\
\text { control }\end{array}$ & $16,2 \pm 0,2$ & - & $18,3 \pm 0,1$ & - \\
\hline Sample 2 & $21,2 \pm 0,2$ & - & $12,4 \pm 0,1$ & - \\
\hline Sample 3 & $22,6 \pm 0,2$ & - & $11,0 \pm 0,1$ & - \\
\hline Sample 4 & $22,8 \pm 0,2$ & - & $10,9 \pm 0,1$ & - \\
\hline $\begin{array}{c}\text { Sample 5 } \\
\text { control }\end{array}$ & - & $16,8 \pm 0,2$ & - & $18,9 \pm 0,1$ \\
\hline Sample 6 & - & $22,0 \pm 0,2$ & - & $12,8 \pm 0,1$ \\
\hline Sample 7 & - & $22,8 \pm 0,2$ & - & $11,4 \pm 0,1$ \\
\hline Sample 8 & - & $23,0 \pm 0,2$ & - & $11,3 \pm 0,1$ \\
\hline
\end{tabular}

Studies have allowed to scientifically substantiate the composition (Tables 1 and 2) and the technological parameters of the production of molded jelly marmalade. Fig. 1 shows the flow chart of molded jelly marmalade on agar with the addition of the food additive "Magnetofood". A distinctive feature of the new technology is the preliminary mixing of the food additive "Magnetofood" with gelling agents, which is used before the technological operation of soaking of gelling agents in cold water. The production technology of jelly marmalade on pectin with the addition of the food additive "Magnetofood" includes the same steps, but has some differences in technological regimes. The technological process of production of molded jelly marmalade involves the following stages: selection and preparation of prescribed components - loose components are sieved, essence, citric acid, the dye are dissolved, starch syrup is heated and filtered; getting a dry mixture of gelling agents with the food additive "Magnetofood" followed by soaking in cold water at a temperature of $(18 \pm 2){ }^{\circ} \mathrm{C}$ for $(50-80) \times 60 \mathrm{~s}$ for agar and $(3,5-4,0) \times 3600 \mathrm{~s}-$ for pectin, thus it happens the solvation of the food additive "Magnetofood" and swelling of the gelling agents with its partial structuring under the action of the nanoparticles of the additive "Magnetofood", which promote water penetration into the most organized parts of the chain of the gelling agents.

Next, the solution of the mixture of the gelling agents with additive "Magnetofood" is heated to a temperature of (95-100) ${ }^{\circ} \mathrm{C}$ for agar and $(85-87){ }^{\circ} \mathrm{C}$ for pectin and kept for (20-25)x60 s for agar and (10-15) $\mathrm{x} 60 \mathrm{~s}$ for pectin. At this stage, the additive "Magnetofood" increases solubility of gelling agents due to its waterholding ability and the interaction of its ionized nanoparticles with polarized agar and pectin groups, which leads to branching of the main chains of polysaccharide molecules, which contributes to their cover and better penetration of water molecules. 
Preparation of jelly-marmalade mass. After the builder completely dissolves, the recipe amount of sugar and starch syrup needed to obtain the jelly mass is added, and mixed thoroughly for $(20-25) \times 60$ s for agar and $(10$ $15) \times 60$ s for pectin, when heated to a temperature $(100$ 105) ${ }^{\circ} \mathrm{C}$; at the same time, sodium lactate is additionally added to the pectin-sugar-molasses syrup. After a uniform distribution, the syrup is boiled down to a mass fraction of dry substances $(75,0 \pm 1) \%$ for agar and $(76,5 \pm 1) \%$ for pectin; cooled to $(55-60){ }^{\circ} \mathrm{C}$ for agar and $(80-85){ }^{\circ} \mathrm{C}$ for pectin and the tempering is carried out, adding diluted dyes, citric acid and essence, according to the composition, with thorough mixing for $(5-7) \times 60 \mathrm{~s}$.

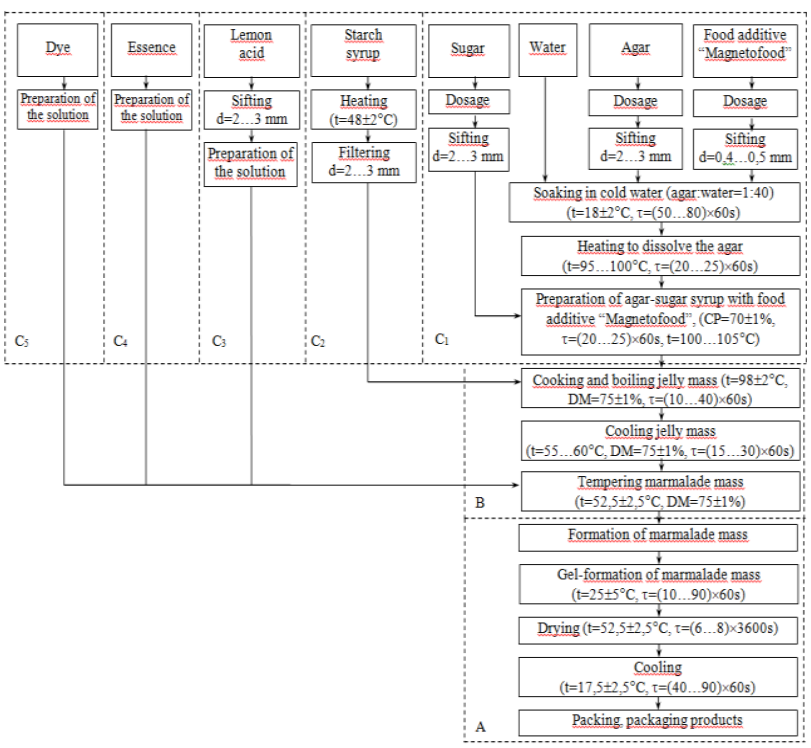

Fig. 1 - Technological scheme of molded jelly marmalade on agar with the addition of the food additive

"Magnetofood": $A, B, C_{1}, C_{2}, C_{3}, C_{4}, C_{5}$ - subsystems of the technological scheme of marmalade production

Cooling and structuring jelly-marmalade mass. The resulting marmalade mass is poured into molds and cooled to a temperature of $(25-30){ }^{\circ} \mathrm{C}$ for structure formation.

Drying jelly marmalade is carried out at a temperature of $(52,5 \pm 2,5){ }^{\circ} \mathrm{C}$ for $(6-8) \times 3600 \mathrm{~s}$ - for agar and (4-6) $\times 3600$ s - for pectin.

Packing, packaging, labeling and storage. Ready molded jelly marmalade is packed and stored in storage conditions at relative air humidity $(75 \pm 2) \%$.

Microbiological indicators of the quality of test samples of molded jelly marmalade were studied. Table 5 shows the microbial contamination of the marmalade surface immediately after manufacture and after storage for 90 days at a relative air humidity $\varphi=(90 \pm 2) \%$.

From the data in Table 5 it follows that the introduction of the food additive "Magnetofood" suppresses the contamination of the surface of marmalade products test samples:
- during storage of marmalade test samples at air humidity $(90 \pm 2) \%$ for 75 days in samples 3, 7 decreases: KMAFAnM 10 times, yeast -3 times, mold fungi -2 times compared with the control;

- during storage of marmalade test samples at air humidity $(90 \pm 2) \%$ for 90 days in samples 3, 7 decreases: KMAFAnM 10 times, yeast - 2,5 times, mold fungi -2 times compared with the control.

This is due to the bacteriostatic action of the food additive "Magnetofood" [18].

Table 5 - The influence of the food additive "Magnetofood" on the microbiological indicators of test samples of molded jelly marmalade compared with the control samples during storage

\begin{tabular}{|c|c|c|c|c|}
\hline \multirow[t]{2}{*}{ Name of indicators } & \multirow[t]{2}{*}{ Standard } & \multicolumn{3}{|c|}{$\begin{array}{l}\text { Test samples of jelly marmalade at } \\
\qquad \varphi=(90 \pm 2) \%\end{array}$} \\
\hline & & $\begin{array}{l}\text { Control } \\
\text { samples }\end{array}$ & Sample 3 & Sample 7 \\
\hline \multicolumn{5}{|c|}{ Shelf life 75 days } \\
\hline $\begin{array}{l}\text { KMAFAnM, KUO/g, } \\
\text { immediately / after } 90 \\
\text { days }\end{array}$ & $1,0 \times 10^{3}$ & $\begin{array}{l}\text { not found } \\
/ 1,0 \times 10^{2}\end{array}$ & $\begin{array}{l}\text { not found } \\
/ 1,0 \times 10^{1}\end{array}$ & $\begin{array}{l}\text { not found } \\
/ 1,0 \times 10^{1}\end{array}$ \\
\hline $\begin{array}{l}\text { Yeast } \mathrm{KUO} / \mathrm{g}, \\
\text { immediately / after } 90 \\
\text { days }\end{array}$ & 50 & $\begin{array}{c}\text { not found } \\
/ 6,0\end{array}$ & $\begin{array}{c}\text { not found } \\
/ 2,0\end{array}$ & $\begin{array}{l}\text { not found } \\
\quad / 2,0\end{array}$ \\
\hline $\begin{array}{l}\text { BGKP (coliforms), in } \\
0,1 \text { g, immediately } / \\
\text { after } 90 \text { days }\end{array}$ & $\begin{array}{c}\text { not } \\
\text { dosed }\end{array}$ & not found & not found & not found \\
\hline $\begin{array}{l}\text { Pathogenic } \mathrm{m} / \mathrm{o}, \\
\text { including bacteria of } \\
\text { the genus Salmonella, } \\
\text { in } 25 \mathrm{~g} \text {, immediately / } \\
\text { after } 90 \text { days }\end{array}$ & $\begin{array}{c}\text { not } \\
\text { dosed }\end{array}$ & not found & not found & not found \\
\hline $\begin{array}{l}\text { Mold fungi KUO/g, } \\
\text { not more than, } \\
\text { immediately / after 90 } \\
\text { days }\end{array}$ & 50 & $\begin{array}{l}\text { not found } \\
\quad / 4,0\end{array}$ & $\begin{array}{l}\text { not found } \\
\quad / 2,0\end{array}$ & $\begin{array}{c}\text { not found } \\
\quad / 2,0\end{array}$ \\
\hline \multicolumn{5}{|c|}{ Shelf life 90 days } \\
\hline $\begin{array}{l}\text { KMAFAnM, KUO/g, } \\
\text { immediately / after } 90 \\
\text { days }\end{array}$ & $1,0 \times 10^{3}$ & $\begin{array}{l}\text { not found } \\
/ 1,0 \times 10^{3}\end{array}$ & $\begin{array}{l}\text { not found } \\
/ 1,0 \times 10^{2}\end{array}$ & $\begin{array}{c}\text { not found } \\
/ 1,0 \times 10^{2}\end{array}$ \\
\hline $\begin{array}{ll}\text { Yeast } & \mathrm{KUO} / \mathrm{g}, \\
\text { immediately } / \text { after } 90 \\
\text { days }\end{array}$ & 50 & $\begin{array}{c}\text { not found } \\
/ 9,0\end{array}$ & $\begin{array}{l}\text { not found } \\
\quad / 4,0\end{array}$ & $\begin{array}{c}\text { not found } \\
\quad / 4,0\end{array}$ \\
\hline $\begin{array}{l}\text { BGKP (coliforms), in } \\
0,1 \text { g, immediately } / \\
\text { after } 90 \text { days }\end{array}$ & $\begin{array}{c}\text { not } \\
\text { dosed }\end{array}$ & not found & not found & not found \\
\hline $\begin{array}{l}\text { Pathogenic } \mathrm{m} / \mathrm{o}, \\
\text { including bacteria of } \\
\text { the genus Salmonella, } \\
\text { in } 25 \mathrm{~g} \text {, immediately / } \\
\text { after } 90 \text { days }\end{array}$ & $\begin{array}{c}\text { not } \\
\text { dosed }\end{array}$ & not found & not found & not found \\
\hline $\begin{array}{l}\text { Mold fungi KUO/g, } \\
\text { not more than, } \\
\text { immediately / after } 90 \\
\text { days }\end{array}$ & 50 & $\begin{array}{l}\text { not found } \\
\quad / 6,0\end{array}$ & $\begin{array}{c}\text { not found } \\
\qquad / 3,0\end{array}$ & $\begin{array}{c}\text { not found } \\
\quad / 3,0\end{array}$ \\
\hline
\end{tabular}

*At $\varphi=(75 \pm 2) \%$ microbial contamination of the surface of test samples of marmalade with the additive "Magnetofood" is reduced on average: KMAFAnM - 10 times; yeast and mold fungi - 5 times compared with the control.

In order to determine the storage conditions, the sorption kinetics of jelly marmalade test samples was studied. The research results are shown in Fig.2, a, b, c, d. 


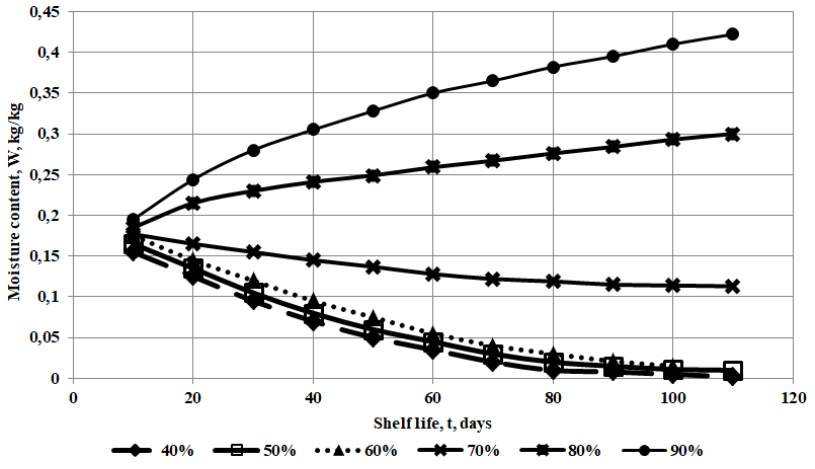

$a$

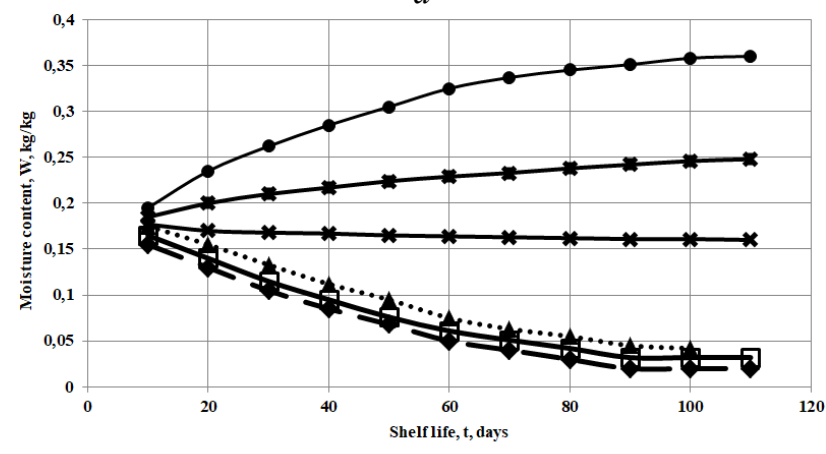

b
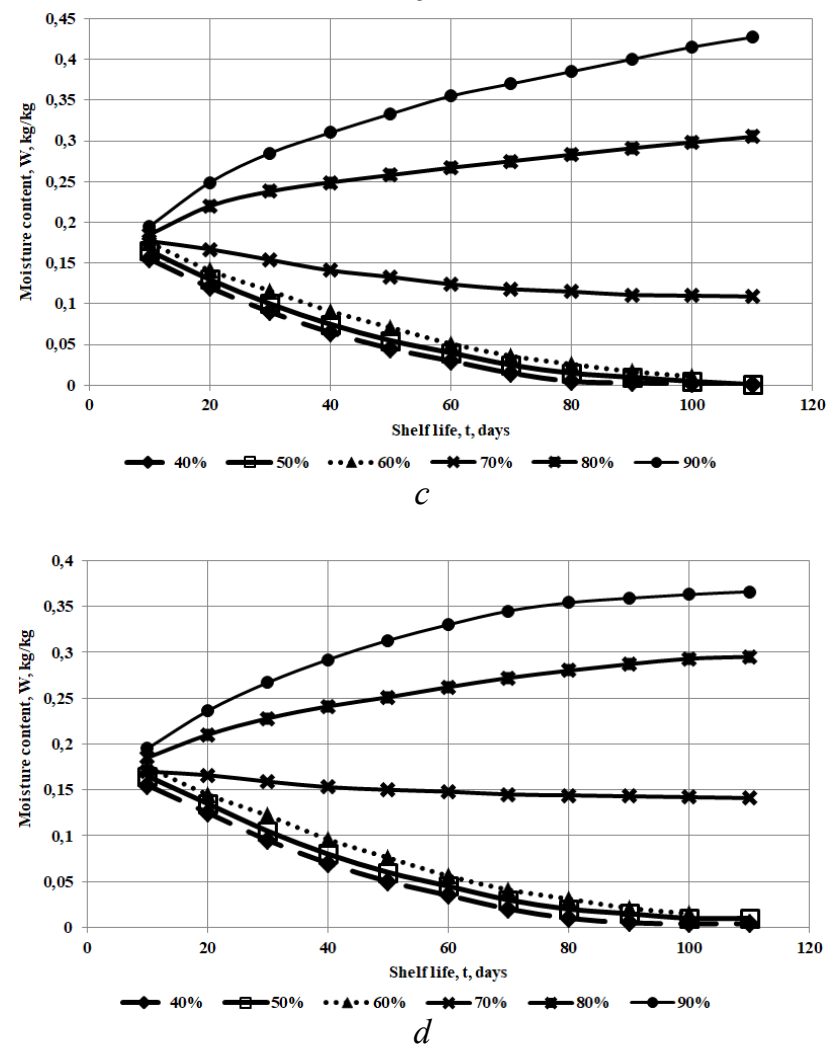

Fig. 2 - Sorption kinetics of test samples of molded jelly marmalade with different air humidity:

$a$ - control sample of 1 marmalade on agar; $b$ - sample of 3 marmalade on agar;

$c$ - control sample of 5 marmalade on pectin; $d$-sample of 7 marmalade on pectin
The analysis of curves given in Fig. 2 shows that at relative air humidity (70-80) \% during recommended shelf lifes (3 months) in all test samples of jelly marmalade the change in moisture content occurs slowly, as can be seen on the corresponding sorption curves. It is established that when the air humidity is $(75 \pm 2) \%$, the samples of jelly marmalade will be characterized by a constant moisture content during the entire shelf life. Fig. 2 also shows that when the air humidity is $(90 \pm 2) \%$, the moisture content of the marmalade gradually increases, that is externally characterized by the development of mold fungi on control samples of marmalade after 90 days of storage (see Table 5). When air humidity is less than $(70 \pm 2) \%$, the sorption curves are directed downwards, which characterizes a decrease in moisture content, gradual drying of the product and leads to loss of organoleptic properties: changes in the shape, structure, hardening of the consistence. When comparing with the control samples (Fig. 2, a, c), it can be seen that the rate of change of moisture content in the test samples of marmalade (Fig. 2, b, d) decreases, which is due to the water-holding and stabilizing ability of the food additive "Magnetofood", namely creation of solvatocomplexes and supramolecular assemblies of nanoparticles "Magnetofood" with macromolecules of polysaccharides, in particular agar, pectin [21].

The results of the criterion Q calculation (see formula 1) for test samples of jelly marmalade are given in Table 6.

Table 6-Criterion Q for test samples of marmalade for a given environmental humidity $(\varphi)$

\begin{tabular}{|c|c|c|c|c|}
\hline \multirow{2}{*}{$\begin{array}{c}\text { Environmental } \\
\text { moisture } \\
\text { content, } \varphi, \%\end{array}$} & \multicolumn{4}{|c|}{$\begin{array}{c}\text { The value of the criterion Q for test } \\
\text { samples of molded jelly marmalade }\end{array}$} \\
\cline { 2 - 5 } & Sample 1 & Sample 3 & Sample 5 & Sample 7 \\
\hline 40 & 1,405 & 1,257 & 1,422 & 1,407 \\
\hline 50 & 1,304 & 1,139 & 1,359 & 1,309 \\
\hline 60 & 1,1079 & 0,990 & 1,236 & 1,189 \\
\hline 70 & 0,490 & 0,480 & 0,521 & 0,319 \\
\hline 80 & 0,876 & 0,492 & 0,879 & 0,824 \\
\hline 90 & 1,679 & 1,378 & 1,744 & 1,400 \\
\hline
\end{tabular}

The analysis of criterion Q (Table 6) sets the smallest total deviation of moisture content $\left(\mathrm{W}_{\mathrm{i}}\right)$ of test samples of molded jelly marmalade from the standard value $\mathrm{W}_{3}=0,180 \mathrm{~kg} / \mathrm{kg}-$ at $\varphi=(70 \pm 2) \%$, which is an additional confirmation of the optimal temperature and humidity conditions for storage of molded jelly marmalade, found from the kinetic sorption curves (Fig. 2): air humidity $\varphi=(75 \pm 2) \%$, temperature $(18 \pm 2){ }^{\circ} \mathrm{C}$.

\section{Conclusions}

The investigation results of the influence of the food additive "Magnetofood" on the quality indicators of molded jelly marmalade showed that the addition of the 
food additive in the amount of $(0,10-0,20) \%$ has a positive effect on the organoleptic, physical and chemical, and microbiological properties of jelly marmalade on agar and pectin, particularly there is an improvement in the following:

- shape, consistency, smell and color on average by $0,1-0,4$ points;

- humidity increases by $(4,8-6,2) \%$ in samples on agar and by $(5,2-6,2) \%$ in samples on pectin due to the water-binding and water-holding ability of the nanoparticles of the additive "Magnetofood";

- total acidity decreases by $(5,9-7,4)^{\circ}$ in samples on agar and by $(6,1-7,6)^{\circ}$ in samples on pectin due to the amphoteric nature of the additive "Magnetofood" and its ability to interact with acidic substances of jellymarmalade masses;

- rational content of the food additive "Magnetofood" was established $-0,15 \%$ by weight of raw materials;

- technological scheme for the production of molded jelly marmalade with the introduction of the food additive "Magnetofood" was developed;

- it has been proven the suppression of microbial surface contamination of jelly marmalade products samples with the food additive "Magnetofood". When stored at $\varphi=(90 \pm 2) \%$ for 75 days in samples 3, 7 compared with the control, the following decreases: KMAFAnM 10 times, yeast -3 times, mold fungi -2 times; and when stored for 90 days - KMAFAnM 10 times, yeast -2.5 times, mold fungi -2 times;

- optimal conditions for temperature and humidity conditions were established during storage of molded jelly marmalade: air humidity $\varphi=(75 \pm 2) \%$, temperature $(18 \pm 2)^{\circ} \mathrm{C}$.

The results obtained suggest that food additive "Magnetofood" is recommended as a stabilizer, structurant and improver for food jelly systems.

\section{Список літератури}

1. Стасіневич, С. А. Ринок кондитерських виробів України: пропозиція і попит / С. А. Стасіневич, С. М. Валявський // Продукты \& ингредиенты. 2013. - № 1. - С. 14-17.

2. Гарби, Е. Желейно-жевательная сладость для украинца / Е. Гарби // Продукты \& ингредиентыл. 2011. - № 2. - С. 40-42.

3. Сегмент пастило-мармеладных изделий и восточных сладостей. Кто определяет тенденции: сост. С. Коптеева [и др.]. - URL: http://myki.ru/articles.php (дата звернення 30.08.2019).

4. Бочковская, Е. Мармелад и желе: или здорово, или доступно покупателю? / Е. Бочковская // Продукты \& ингредиенты. - 2013. - № 2. - С. 14-17.

5. Иоргачева, E. Г. Жевательные и желейные мармелады / Е. Г. Иоргачева // Кондитерское $u$ хлебопекарное производство. - 2010. - № 1. - С. $54-55$.

6. Васькина, В. А. Сравнительная характеристика технологий желейного мармелада / В. А. Васькина
// Кондитерское и хлебопекарное производство. 2004. - T. 6. - № 34. - С. 1-4.

7. Иоргачева, Е. Г. Регулирование качества желейного мармелада с измененным углеводным составом / E. Г. Иоргачева, К. В. Аветисян // Восточноевропейский журнал передовых технологий. - 2016. - T. 2. - № 11(80). - C. 28-38. - doi: 10.15587/1729-4061.2016.65768.

8. Иоргачева, Е. Г. Регулирование структурнореологических свойств желейних и сбивных масс для двухслойного мармелада / Е. Г. Иоргачева, О. В. Макарова, К. В. Аветисян // Восточноевропейский журнал передовых технологий. -2014. T. 2. - № 12 (68). - C. 122-127. - doi: 10.15587/1729-4061.2014.23380.

9. Salieva, A. Pectin substances from sea and freshwater grasses as stabilizers at manufacturing of canned food of type confiture / A. Salieva // Vestnik of Astrakhan State Technical University. - 2013. - 1. - P. 194-200.

10. Yang, Y. Calcium cation triggers and accelerates the gelation of high methoxy pectin / Y.Yang, G. Zhang, Y. Hong, Z.Gu, F. Fang // Food Hydrocolloids. 2013. -Vol. 32. - 2. - P. 228-234. - doi: 10.1016/j.foodhyd.2013.01.003.

11. Kaya, M. Characterization of citrus pectin samples extracted under different conditions: Influence of acid type and $\mathrm{pH}$ of extraction / M. Kaya, A. G. Sousa, M. J. Crepeau, S. O. Sorensen, M. C. Ralet // Annals of Botany. - 2014. - Vol. 114. - 6. - P. 1319 1326. - doi: $10.1093 / \mathrm{aob} / \mathrm{mcu} 150$.

12. Zhang, X. Preparation of hydroxypropyl agars and their properties / X. Zhang, X. Liu, M. Cao, K. Xia, Y. Zhang // Carbohydr. Polym. - 2015. - 129. - P. 8791. - doi: 10.1016/j.carbpol.2015.04.056.

13. Schirmer, M. Physicochemical interactions of polydextrose for sucrose replacement in pound cake / M. Schirmer, M. Jekle, E. Arendt, T. Becker // Food Research International. - 2012. - Vol. 48. - 1. P. 291-298. - doi: 10.1016/j.foodres.2012.05.003.

14. Артамонова, М. В. Технологія мармеладу желейного 3 використанням кріас-порошків рослинного походження: монографія / М. В. Артамонова, Г. М. Лисюк, Н. Ф. Туз. - Харків: ХДУХТ. - 2015. $184 \mathrm{c}$.

15. Драгилев, А. И. Технология кондитерских изделий / А. И. Драгилев, А. И. Лурье. - М.: ДеЛи-принт. 2001. - 483 c

16. Сарафанова, Л. А. Применение пищевых добавок в кондитерской промышленности / Л. А. Сарафанова. - СПб: Профессия. - 2005. - 304 с.

17. Tsykhanovska, I. V. Investigation of magnetite nanoparticles of lipid-magnetite suspensions by methods of photometry and electron microscopy / I. V. Tsykhanovska, O. V. Aleksandrov, T. B. Gontar, Z. V. Barsova, M. G. Kokodiy // East European Journal of Advanced Technologies. - 2016. - Vol.6/3. - 81. P. 28-38. - doi: 10.15587/1729-4061.2016.69826.

18. Ilyukha, N. G. Production technology and quality indices of a food additive based on magnetite / N. G. Ilyukha, I. V. Tsykhanovska, Z. V. Barsova, V. A. Kovalenko // East European Journal of Advanced Technologies. - 2010. - Vol. 6. - 48. - P. $32-35$.

19. Tsykhanovska, I. V. Development of technology of rye-wheat bread "Kharkiv Rodnichok" with the addition of a multifunctional nutritional supplement "Magnetofood" / I. V. Tsykhanovska, O. V. 
Aleksandrov, V. V. Evlash, T. A. Lazareva, K. V. Svidlo, T. B. Gontar // East European Journal of Advanced Technologies. - 2017. - Vol. 6/11. - 90. - P. $48-58$.

20. Tsykhanovska, I. Substantiation of the interaction mechanism between the lipo- and glucoproteids of ryewheat flour and nanoparticles of the food additive "Magnetofood" / I. Tsykhanovska, A. Alexandrov, V. Evlash, T. Lazareva, O. Bryzytska // East European Journal of Advanced Technologies. - 2018. - Vol. 4 /11. - 94. - P. 61-68. - doi: 10.15587/17294061.2018.140048

21. Tsykhanovska, I. Substantiation of the mechanism of interaction of carbohydrates of rye-wheat flour and nanoparticles of the polyfunctional food additive "Magnetofood" / I. Tsykhanovska, A. Alexandrov, V. Evlash, T. Lazareva, T. Yevlash // East European Journal of Advanced Technologies. - 2018. - Vol. 3 /11. - 93. - P. 59-68. - doi: 10.15587/1729 4061.2018 .133373

22. Tsykhanovska, I. Formation of the functional and technological properties of the beef minced meat by using the food additive on the nanopowder basis of double oxide of two- and trivalent iron / I. Tsykhanovska, L. Skurikhina, V. Evlash, L. Pavlotska // Ukrainian food journal. - 2018. - Vol. 7. - 3. - P. 379-396. - doi: 10.24263/2304-974X-2018-73-4.

23. Бабаходжаев, С. Ф. Мармелад на хлопковом пектине / С. Ф. Бабаходжаев // Пишевая промышленность. - 1991. - № 2. - С. 54.

24. Прназарова, У. Пектиновые вещества из отходов пищевых производств / У. Прназарова, А. $\mathbf{X}$ Арифходжаев, Х. T. Саломов // Пищевая промышиленность. - 1991. - № 2. - С. 55.

25. Крапивницкая, И. А. Овощные и фруктовоовощные пектиносодержащие продукты в отделочных полуфабрикатах c желейной структурой / И. А. Крапивницкая, В. И. Оболкина, У. С. Йовбак // Кондитерское производство. - 2014. - № 5. - С. 33-34.

26. Иоргачева, Е. Г. Альтернативные виды сырья в технологии получения пастило-мармеладных изделий / Е. Г. Иоргачева, К. В. Аветисян, А. В. Куц // Хлібопекарська $i$ кондитерська промисловість України. - 2009. - № 1. - С. 14-16.

27. Гурьянов, И. Д. Хитозан в производстве желейного мармелада / И. Д. Гурьянов, 3. И. Фаизрахманова, Д. И. Фаизрахманова // Вестник Казанского технологического университета. - 2014. - № 7. C. $205-208$

28. Донченко, Л. В. Пектин: основные свойства, производство и применение / Л. В. Донченко, Г. Г. Фирсов. - М.: ДеЛи-принт. - 2007. - 276 с.

29. Фощан, А. Л. Регулювання реологічних та структурно-механічніх властивостей желейних виробів та напівфабрикатів на основі комбінованих систем драгле утворювачів / А. Л. Фощан // Хлібопекарська $i$ кондитерська промисловість України. - 2010. - № 2. - С. 29-30.

30. Гриненко, И. Г. Некоторые закономерности образования инулиновых гелів / И. Г. Гриненко, Р. И. Грушецкий, Л. М. Хомичак // Сахар: Научнотехнический и производственный журнал. - 2014. № 11. - C. $54-55$.
31. Шебершнева, Н. Н. Использование рикогеля 8100 в производстве желейного мармелада / Н. Н. Шебершнева // Кондитерское производство. - 2013. - № 6. - C. 15-16.

32. Игнатова, T. А. Использование гидрогелей каррагинанов в технологии желейных продуктов / T. А. Игнатова, А. В. Подкорытова // Актуальные проблемь освоения биологических ресурсов мирового океана: материаль III Междунар. науч.-техн. конф. в 2 частях. Владивосток: Дальрыбвтуз. - 2014. - С. $58-63$

33. Теймурова, А. T. Розробка технологій желейної продукції 3 використанням концентратів тваринних білків: автореф. дис... канд. техн. наук: 05.18.16 / НАН України. -Харків: Харьківский державний університет харчування та торгівлі, 2010. - 18 с.

34. Осипов, А. Пектины и каррагинаны для кондитерских изделий. Новые возможности традиционных ингредиентов / А. Осипов // Кондитерское производство. - 2012. - № 5. - С 18-19.

35. Маренкова, T. I. Спосіб отримання мармеладу желейного формового на каппа-карагінані 3 якісно зміненими функціонально-технологічними властивостями. Патент 94598 UА. МПК А23L 1/00. -2014. - Бюл. № 22. -4 с.

36. Фощан, А. Л., Григоренко, А. М. Спосіб підвищення міцності драглівсульфатних полісахаридів. Патент 61370 UA. МПК А 23 L 1/ 06. - 2014. - Бюл. № 14. - 4 с.

37. Овсянникова, Л. полисахаридов для сокращения расхода студнеобразователей из красных морских водоростей / Л. Г. Овсянникова // Сборник материалов науч.техн. конференции "Прогрессивные технологии и оборудование пищевых производств». - СПб: ГАХПТ. - 1999. - С. 183.

38. Евалева, В. В. Лактатсодержащие пищевые добавки и мармелад функционального назначения / В. В. Евалева, Т. М. Черпалова, Т. А. Никифорова // Кондитерское производство. - 2013. - № 6. - С. 13-16.

39. Свиридов, В. В. Влияние природы студнеобразователя на свойства пищевых студней / В. В. Свиридов, А. В. Банникова, Н. М. Птичкина // Известия вузов. Пищевая технология. 2012. - № 1. - С. 59-61.

40. Шеховцова, Т. Г. Разработка технологии желейного мармелада с заданными потребительскими свойствами / Т. Г. Шеховцова, Ю. И. Сидоренко // Хранение и переработка сельхозсырья. - 2008. - № 8. - C.65-67.

41. Золотарева, Л. А. Структурообразователи и прочностные свойства желейных изделий / Л. А. Золотарева, К. В. Аветисян // Хлібопекарська $i$ кондитерська промисловість України. - 2007. - № 4. - C.40-41.

42. Крапивницька, I. О. Наукові та практичні аспекти пектину i пектинопродуктів: монографія / I. O. Крапивницька, Ф. В. Перцевой, С. О. Омельчук. Суми: Сумський національний аграрний університет. - 2015. - 314 с.

43. Аймесон, А. Пищевые загустители, стабилизаторы, гелеобразователи / пер. С. В. Макарова. - СПб.: ИД «Профессия». - 2012. - 408 с. 
44. Голубев, В. Н. Функциональные свойства пектинов и крахмала / В. Н. Голубев, С. Ю. Беглов, А. В. Поджуев // Пищевые ингредиенты. Сырье и добавки. - 2000. - № 1. - C. 14-18.

45. Мазур, Л. М. Физико-химические процессы гелеобразования пектинов в пищевых технологіях / Л. М. Мазур, А. А. Олехнович // Сахар. - 2014. № 1. - C. 2-5.

46. Карнаушенко, Л. И. Реологические свойства желейных масс / Л. И. Карнаушенко, Э. И. Погонцева, Э. И. Чмырь // Кондитерская хлебопекарная промышленность. - 1981. - № 3. - С. 41-42.

47. Иванушко, Л. С. Рецептуры на мармелад, пастилу и зефир / Л. С. Иванушко. - М.: Пищевая промышленность. - 1974. - 208 с.

48. Штайер, P. Многокритериальная оптимизация Теория, вычисления и приложения: [пер. с английского] / Р. Штайер. - М.: Радио и свіязь. 1992. - 504 c.

49. Свлаш, В. В. Наукові аспекти формування якості дієтичних добавок, що містять гемове залізо, та кондитерських виробів із їх використанням: монографія / В. В. Євлаш, В. О. Акмен. - Харків: ХДУХТ. - 2015. - 183 с.

\section{References (transliterated)}

1. Stasinevy`ch, S. A., Valyavs'ky’j, S. M. Ry`nok kondy`ters`ky`x vy`robiv Ukrayiny`: propozy`ciya i popy`t. Produkty \& ingredienty, 2013, 1, 14-17.

2. Garbi, E. Zhelejno-zhevatel'naja sladost' dlja ukrainca. Produkty \& ingredienty, 2011, 2, 40-42.

3. Segment pastilo-marmeladnyh izdelij i vostochnyh slabostej. Kto opredeljaet tendencii: sost. Kopteeva S. [i dr.]. Available at: http://my-ki.ru/articles.php. (data zvernennja 30.08.2019).

4. Bochkovskaja, E. Marmelad i zhele: ili zdorovo, ili dostupno pokupatelju? Produkty \& ingredienty, 2013, 2, $14-17$.

5. Iorgacheva, E. G. Zhevatel'nye i zhelejnye marmelady Konditerskoe $i$ hlebopekarnoe proizvodstvo. 2010, 1, 54-55.

6. Vas'kina, V. A. Sravnitel'naja harakteristika tehnologij zhelejnogo marmelada. Konditerskoe $i$ hlebopekarnoe proizvodstvo, 2004, 6 (34), 1-4.

7. Iorgacheva, E. G., Avetisjan, K. V. Regulirovanie kachestva zhelejnogo marmelada $\mathrm{s}$ izmenennym uglevodnym sostavom. Vostochno-evropejskija zhurnal peredovih tehnologij, 2016, 2, 11(80), 28 - 38, doi: 10.15587/1729-4061.2016.65768.

8. Iorgacheva, E. G., Makarova, O. V., Avetisjan, K. V. Regulirovanie strukturno-reologicheskih svojstv zhlejnih i sbivnyh mass dlja dvuhslojnogo marmelada. Vostochno-evropejskij zhurnal peredovyh tehnologij, $2014, \quad 2, \quad 12$ (68), 122-127, doi: 10.15587/17294061.2014.23380.

9. Salieva, A. Pectin substances from sea and freshwater grasses as stabilizers at manufacturing of canned food of type confiture. Vestnik of Astrakhan State Technical University, 2013, 1, 194-200.

10. Yang, Y., Zhang, G., Hong, Y., Gu, Z., Fang, F. Calcium cation triggers and accelerates the gelation of high methoxy pectin. Food Hydrocolloids, 2013, 32 (2), 228-234, doi: 10.1016/j.foodhyd.2013.01.003.
11. Kaya, M., Sousa, A. G., Crepeau, M. J., Sorensen, S. O., Ralet, M. C. Characterization of citrus pectin samples extracted under different conditions: Influence of acid type and $\mathrm{pH}$ of extraction. Annals of Botany, 2014, 114 (6), 1319-1326, doi: 10.1093/aob/mcu150.

12. Zhang, X., Liu, X., Cao, M., Xia, K., Zhang, Y. Preparation of hydroxypropyl agars and their properties. Carbohydr. Polym., 2015, 129, 87-91, doi: 10.1016/j.carbpol.2015.04.056.

13. Schirmer, M., Jekle, M., Arendt, E., Becker, T. Physicochemical interactions of polydextrose for sucrose replacement in pound cake. Food Research International, 2012, 48(1), 291-298, doi: 10.1016/j.foodres.2012.05.003.

14. Artamonova, M. V., Lisjuk, G. M., Tuz, N. F. Tehnologija marmeladu zhelejnogo $\mathrm{z}$ vikoristannjam krias-poroshkiv roslinnogo pohodzhennja: monografija. Harkiv: HDUHT, 2015, 184.

15. Dragilev, A. I., Lur'e, A. I. Tehnologija konditerskih izdelij. Moskva: DeLi-print, 2001, 483.

16. Sarafanova, L. A. Primenenie pishhevyh dobavok v konditerskoj promyshlennosti. SPb: Professija, 2005, 304.

17. Tsykhanovska, I. V., Aleksandrov, O. V.,Gontar, T. B., Barsova, Z. V., Kokodiy, M. G. Investigation of magnetite nanoparticles of lipid-magnetite suspensions by methods of photometry and electron microscopy. East European Journal of Advanced Technologies, 2016, 6/3 (81), 28 - 38, doi: 10.15587/1729-4061.2016.69826.

18. Ilyukha, N. G., Tsykhanovska, I. V., Barsova, Z. V., Kovalenko, V. A. Production technology and quality indices of a food additive based on magnetite. East European Journal of Advanced Technologies, 2010, 6 (48), $32-35$.

19. Tsykhanovska, I. V., Aleksandrov, O. V., Evlash, V. V., Lazareva, T. A., Svidlo, K. V., Gontar, T. B. Development of technology of rye-wheat bread "Kharkiv Rodnichok" with the addition of a multifunctional nutritional supplement "Magnetofood". East European Journal of Advanced Technologies, 2017, 6/11 (90), 48 $-58$.

20. Tsykhanovska, I., Alexandrov, A., Evlash, V., Lazareva, T., Bryzytska O. Substantiation of the interaction mechanism between the lipo- and glucoproteids of rye-wheat flour and nanoparticles of the food additive "Magnetofood". East European Journal of Advanced Technologies, 2018, 4/11 (94), 6168, doi: 10.15587/1729-4061.2018.140048.

21. Tsykhanovska, I., Alexandrov, A., Evlash, V., Lazareva, T., Yevlash, T. Substantiation of the mechanism of interaction of carbohydrates of rye-wheat flour and nanoparticles of the polyfunctional food additive "Magnetofood". East European Journal of Advanced Technologies, 2018, 3/11 (93), 59-68, doi: 10.15587/1729-4061.2018.133373.

22. Tsykhanovska, I., Skurikhina, L., Evlash, V., Pavlotska, L. Formation of the functional and technological properties of the beef minced meat by using the food ad-ditive on the nanopowder basis of double oxide of two- and trivalent iron. Ukrainian food journal, 2018, 7 (3), 379-396, doi: 10.24263/2304974X-2018-7-3-4.

23. Babahodzhaev, S. F. Marmelad na hlopkovom pektine. Pishhevaja promyshlennost'. 1991, 2, 54. 
24. Prnazarova, U., Arifhodzhaev, A. H., Salomov, H. T. Pektinovye veshhestva iz othodov pishhevyh proizvodstv. Pishhevaja promyshlennost', 1991, 2, 55.

25. Krapivnickaja, I. A., Obolkina, V. I., Jovbak, U. S. Ovoshhnye i fruktovo-ovoshhnye pektinosoderzhashhie produkty $\mathrm{v}$ otdelochnyh polufabrikatah $\mathrm{s}$ zhelejnoj strukturoj. Konditerskoe proizvodstvo, 2014, 5, 33-34.

26. Iorgacheva, E. G., Avetisjan, K. V., Kuc, A. V. Al'ternativnye vidy syr'ja $\mathrm{V}$ tehnologii poluchenija pastilo-marmeladnyh izdelij Hlibopekars'ka $i$ konditers'ka promislovist' Ukraïni, 2009, 1, 14-16.

27. Gur'janov, I. D., Faizrahmanova, Z. I., Faizrahmanova, D. I. Hitozan v proizvodstve zhelejnogo marmelada. Vestnik Kazanskogo tehnologicheskogo universiteta, 2014, 7, 205-208.

28. Donchenko, L. V. Pektin: osnovnye svojstva, proizvodstvo i primenenie. M.: DeLi-print, 2007, 276.

29. Foshhan, A. L. Regulyuvannya reologichny'x ta strukturno-mexanichnix vlasty`vostej zhelejny`x vy`robiv ta napivfabry'kativ na osnovi kombinovany`x sy`stem dragle utvoryuvachiv. Xlibopekars'ka $i$ kondy'ters `ka promy 'slovist' Ukrayiny', 2010, 2, 29-30.

30. Grinenko, I. G., Grusheckij, R. I., Homichak, L. M. Nekotorye zakonomernosti obrazovanija inulinovyh gelej. Sahar: Nauchno-tehnicheskij $i$ proizvodstvennyj zhurnal, 2014, 11, 54-55.

31. Shebershneva, N. N. Ispol'zovanie rikogelja 8100 v proizvodstve zhelejnogo marmelada. Konditerskoe proizvodstvo, 2013, 6, 15-16.

32. Ignatova, T. A., Podkorytova, A. V. Ispol'zovanie gidrogelej karraginanov $\mathrm{v}$ tehnologii zhelejnyh produktov. Aktual'nye problemy osvoenija biologicheskih resursov mirovogo okeana: materialy III Mezhdunar. nauch.-tehn. konf. $v 2$ chastjah. Vladivostok: Dal'rybvtuz, 2014, 58-63.

33. Tejmurova, A. T. Rozrobka texnologij zhelejnoyi produkciyi $\mathrm{z}$ vy'kory`stannyam koncentrativ tvary`nny' $\mathrm{x}$ bilkiv: avtoref. dy's. kand. texn. nauk. Xarkiv: Xar`kivsky`j derzhavny`j universy`tet xarchuvannya ta torgivli, 2010, 18

34. Osipov, A. Pektiny i karraginany dlja konditerskih izdelij. Novye vozmozhnosti tradicionnyh ingredientov. Konditerskoe proizvodstvo, 2012, 5, 18-19.

35. Marenkova, T. I. Patent 94598 UA. MPK A23L 1/00 Sposib otry`mannya marmeladu zhelejnogo formovogo na kappa-karaginani z yakisno zmineny`my funkcional'no-texnologichny 'my' vlasty`vostyamy`. 2014 Byul. 22.

36. Foshhan, A. L., Gry`gorenko, A. M. Patent 61370 UA. MPK A 23 L 1/ 06 . Sposib pidvy`shhennya micznosti draglivsul’fatny`x polisaxary`div. 2011, Byul.14.
37. Ovsjannikova, L. G. Ispol'zovanie kislyh polisaharidov dlja sokrashhenija rashoda studneobrazovatelej iz krasnyh morskih vodorostej. Sbornik materialov nauch.tehn. konferencii «Progressivnye tehnologii $i$ oborudovanie pishhevyh proizvodstv», $\mathrm{SPb}$ : GAHPT, 1999, 183.

38. Evaleva, V. V., Cherpalova, T. M., Nikiforova, T. A. Laktatsoderzhashhie pishhevye dobavki i marmelad funkcional'nogo naznachenija. Konditerskoe proizvodstvo, 2013, 6, 13-16.

39. Sviridov, V. V., Bannikova, A. V., Ptichkina, N. M. Vlijanie prirody studneobrazovatelja na svojstva pishhevyh studnej. Izvestija vuzov. Pishhevaja tehnologija, 2012, 1, 59-61.

40. Shehovcova, T. G., Sidorenko, J. Razrabotka tehnologii zhelejnogo marmelada $\mathrm{s}$ zadannymi potrebitel'skimi svojstvami. Hranenie $i$ pererabotka sel'hozsyr'ja, 2008, 8, 65-67.

41. Zolotareva, L. A., Avetisjan, K. V. Strukturoobrazovateli i prochnostnye svojstva zhelejnyh izdelij. Xlibopekars 'ka $i$ kondy`ters `ka promy`slovist' Ukrayiny', 2007, 4, 40-41.

42. Krapy`vny`cz'ka, I. O., Percevoj, F. V., Omel`chuk, Ye. O. Naukovi ta prakty`chni aspekty' pekty`nu i pekty`noproduktiv: monografiya. Sumy`: Sums`ky`j nacional'ny`j agrarny` $j$ universy`tet, 2015, 314.

43. Ajmeson, A. Pishhevye zagustiteli, stabilizatory, geleobrazovateli: per. Makarova SV. SPb.: ID «Professija», 2012, 408.

44. Golubev, V. N., Beglov, S. Ju., Podzhuev, A. V. Funkcional'nye svojstva pektinov i krahmala. Pishhevye ingredienty. Syr'e i dobavki, 2000, 1, 14-18.

45. Mazur, L. M., Olehnovich, A. A. Fiziko-himicheskie processy geleobrazovanija pektinov $\mathrm{V}$ pishhevyh tehnologijah. Sahar, 2014, 1, 2-5.

46. Karnaushenko, L. I., Pogonceva, Je. I., Chmyr', A. D. Reologicheskie svojstva zhelejnyh mass. Konditerskaja $i$ hlebopekarnaja promyshlennost', 1981, 3, 41-42.

47. Ivanushko, L S. Receptury na marmelad, pastilu i zefir. M.: Pishhevaja promyshlennost', 1974, 208.

48. Shtajer, R. Mnogokriterial'naja optimizacija. Teorija, vychislenija i prilozhenija: [per. s anglijskogo]. M.: Radio i svjaz', 1992, 504.

49. Yevlash, V. V., Akmen, V. O. Naukovi aspekty` formuvannya yakosti diyety'chny'x dobavok, shho mistyat' gemove zalizo, ta kondy`ters`ky'x vy`robiv iz yix vy`kory`stannyam: monografiya. Xarkiv: XDUXT, $2015,183$.

\section{Відомості про авторів (About authors)}

Iryna Tsykhanovska - Candidate of Chemical Sciences, Ukrainian Engineering Pedagogics Academy, Associate Professor of the Food and Chemical Technologies Department; Kharkiv, Ukraine; ORCID: 0000-0002-9713-9257; e-mail: Cikhanovskaja@gmail.com.

Цихановська Ірина Василівна- кандидат хімічних наук, Українська інженерно-педагогічна академія, доцент кафедри харчових та хімічних технологій; м. Харків, Україна; ORCID: 0000-0002-9713-9257; e-mail: Cikhanovskaja@gmail.com.

Please cite this article as

Tsykhanovska, I. Development of molded jelly marmelad technology with the introduction of food additive "Magnetofood". Bulletin of NTU "KhPI". Series: New solutions in modern technologies. - Kharkiv: NTU "KhPI", 2019, 10 (1335), 109-120, doi:10.20998/2413-4295.2019.10.14. 
Будь ласка, посилайтесь на июю статтю наступним чином:

Цихановська, І. В. Розробка технології формового желейного мармеладу 3 внесенням харчової добавки “Магнетофуд” / І. В. Цихановська // Вісник НТУ «ХПІ», Серія: Нові рішення в сучасних технологіях. - Харків: НТУ «ХПІ». - 2019. - № 10 (1335). - C. 109-120. - doi:10.20998/2413-4295.2019.10.14.

Пожалуйста, ссылайтесь на эту статью следующим образом:

Цихановская, И. В. Разработка технологии формового желейного мармелада с введением пищевой добавки «Магнетофуд» / И. В. Цихановская // Вестник НТУ «ХПИ», Серия: Новые решения в современных технологиях. - Харьков: НТУ «ХПИ». - 2019. - № 10 (1335). - С. 109-120. - doi:10.20998/2413-4295.2019.10.14.

АННотАЦИЯ Дефицит отечественного сырья, значительная часть импортных ингредиентов с высокой стоимостью, растущая конкурентоспособность заставляют производителей искать новые технологические решения для повышения потребительских свойств мармеладной продукции. Перспективным направлением в области желейно-мармеладных изделий является создание продукиии, которая имеет высокие показатели качества и длительный срок хранения. $C$ этой целью в технологии желейного мармелада используются различные пищевые добавки - улучшители. В качестве улучшителя формового желейного мармелада нами разработана и предложена пищевая добавка "Магнетофуд" - нанопорошок $c$ размером частии (70-80) нм. "Магнетофуд” - пищевая добавка с высоким функиионально-технологическим потенциалом. Добавка "Магнетофуд” может как самостоятельно формировать структурно-механические свойства желейных масс, так и влиять на гелеобразователь, вступая с ним в химические и электростатические взаимодействия. Поэтому, пищевая добавка "Магнетофуд” може влиять сразу на несколько технологических свойств в пищевой желейные системе: быть стабилизатором, загустителем, студнеобразователем. За счет Fе (II), наноразмеров, развитой активной поверхности, бактериостатичности, высокой термостабильности "Магнетофуд" имеет восстановительные, антиоксидантные, антимикробные, сорбиионные, комплексообразующие, эмульгирующие, влагоудерживающие, жироудерживающие, водосвязывающие, стабилизирующие, структурирующие свойства. Это позволяет рекомендовать “Магнетофуд”как добавку комплексного действия для повымения качества и продления срока хранения формового желейного мармелада. Исследовано влияние пищевой добавки “Магнетофуд" на органолептические, физико-химические, микробиологические показатели опытных образиов формового желейного мармелада на агаре и пектине.

Ключевые слова: технология; пищевая добавка "Магнетофуд"; формовой желейный мармелад; показатели качества.

Поступила (received) 23.04.2019 